\title{
PENGEMBANGAN BAHAN AJAR MATA PELAJARAN AKUNTANSI PERBANKAN DAN KEUANGAN MIKRO BERBASIS CONTEXTUAL TEACHING AND LEARNING (CTL)
}

\author{
Novandhi Setyawan Putra ${ }^{1}$, Rochmawati ${ }^{2}$ \\ Program Studi Pendidikan Akuntansi, Fakultas Ekonomi, Universitas Negeri Surabaya \\ 1novandhiputra16080304023@mhs.unesa.ac.id, ${ }^{2}$ rochmawati@unesa.ac.id
}

\begin{abstract}
This study included in $R \& D$ (Research and Development). Development model using 4-D from Thiagarajan, Semmel, and Semmel, namely define, design, and develop. However, disseminate stage is not carried out. The goal of this development research is to produce products of teaching materials bank accounting and micro finance based on Contectual Teaching and Learning (CTL), and to analyze feasibility of teaching material products. To analyze the feasibility of teaching materials, researcher uses review and validation sheet as the instrument of review activity. The reviewers and validators of the material done by teachers of SMKN 10 Surabaya and lecturer of Accounting Education UNESA, linguistic by lecturer of language department UNESA, and graphics by lecturer of Educational Technology department of UNESA. The results of this study show that material eligibility and content presentation obtain $86 \%$ with very feasible criteria, language eligibility obtain $80 \%$ with feasible criteria, graphics eligibility obtain 98,9\% with very feasible criteria and the average eligibility of teaching materials obtain $88,3 \%$ with very feasible criteria.
\end{abstract}

Keywords: Teaching Materials, Contextual Teaching and Learning (CTL), Bank accounting and micro finance.

\section{Pendahuluan}

Pendidikan adalah salah satu sarana menciptakan individu yang cerdas, kreatif, kritis, dan berkualitas. Halesuai dengan pernyataan Hamalik (2015), bahwa proses pendidikan sangat terkait dan tidak terpisahkan dengan manusia dalam proses membangun dirinya. sehingga diharapkan terciptalah individu yang berkualitas. Untuk mencapai tujuan pendidikan tersebut, pemerintah telah menjalankan beberapa cara, diantaranya perubahan dan penyempurnaan kurikulum. Kurikulum saat ini adalah Kurikulum 2013 edisi revisi. Kurikulum ini menekankan kegiatan belajar mengajar yang berpusat pada peserta didik, agar mampu berpikir secara kritis dalam pembelajaran saintifik. Dalam pendidikan di Indonesia, terdapat sekolah yang memiliki fokus untuk membentuk 2 kemampuan ketrampilan dan pengetahuan yaitu Sekolah Menengah Kejuruan (SMK). Terdapat beberapa kompetensi keahlian dalam SMK, salah satunya yakni perbankan. Kompetensi keahlian perbankan ini didalamnya membahas tentang dasar-dasar dalam dunia perbankan, pencatatan transaksitransaksi yang terjadi didalam dunia perbankan dan memuat segala pengetahuan tentang perbankan lainnya. Sehingga, dengan adanya kompetensi keahlian ini maka akan berkontribusi dalam penyiapan individu berkompeten di bidang perbankan dan berdaya saing dalam dunia kerja yang kompetitf.

Untuk mewujudkan kompetensi keahlian yang diharapkan tersebut, dalam pembelajaran diperlukan tujuan pembelajaran yang harus dicapai oleh pendidik. Dick \& Carey dalam Uno (2016) menyatakan tujuan pembelajaran digunakan oleh pendidik untuk menentukan segala sesuatu yang berkaitan dengan aktivitas peserta didik ketika selesai melaksanakan proses pembelajaran. Tujuan pembelajaran tersebut dapat dicapai dengan penggunaan sebuah bahan yang dapat di implementasikan saat kegiatan pembelajaran atau disebut sebagai sumber

DOI: 10.33603/ejpe.v8i2.3677 
belajar. Komalasari (2017) menyatakan bahwa sumber belajar sangat membantu pendidik guna mencapai tujuan pembelajaran secara efektif. Dalam penerapannya, sumber belajar terdiri dari beberapa macam, salah satunya adalah bahan ajar. Prastowo (2015) menyatakan bahan ajar ialah sekumpulan kertas berisi materi dengan susunan lengkap sesuai kompetensi serta dapat diimplementasikan untuk belajar. Nasution (2013) menyatakan bahwa bahan ajar sangat menolong pendidik dalam proses pemberian informasi. Bahan ajar yang menarik dan sejalan dengan kurikulum yang berlaku sangat disarankan. Pentingnya hal tersebut didukung oleh penelitian Pertiwi \& Rochmawati (2019) yang menyatakan bahwa memang diperlukan bahan ajar dengan daya tarik tinggi untuk peserta didik agar dibaca.

Dalam upaya memudahkan peserta didik dalam kegiatan belajar sekaligus sesuai dengan implementasi kurikulum perlu adanya penggunaan bahan ajar berbasis kontekstual (Contextual Teaching and Learning). Menurut Sagala (2012) pendekatan kontekstual adalah konsep pengaitan teori dalam materi dengan lingkungan kehidupan peserta didik. Johnson (2007) menyatakan bahwa dengan pembelajaran kontekstual peserta didik dituntut untuk selalu mencari sebuah makna yang terdapat dalam pengaitan teori pelajaran dengan kondisi nyata lingkungan yang akan memudahkan dalam hal pemahaman dan pendalaman materi. Bahan ajar berbasis kontekstual dianggap sebagai solusi untuk memacu peserta didik agar tercipta pemikiran yang kreatif melalui kegiatan pengaitan teori dengan kehidupan nyata (Rahmawati \& Susanti, 2019). Hasil penelitian Toyib, Martono, \& Sawiji (2015) juga mengemukakan bahwa dalam kelas, pengaplikasian bahan ajar kontekstual lebih berhasil dibanding bahan ajar biasa. Oleh karena itu, penjabaran materi dengan kontekstual lebih mempermudah peserta didik memahami dan mendalami materi yang dijelaskan (Widiyawati \& Susanti, 2017). Selain berbasis kontekstual, pemilihan bahan ajar yang sesuai dengan kompetensi di SMK sangat diperlukan dalam kegiatan pembelajaran. Hal itu sesuai dengan penelitian Ma'sum \& Rochmawati (2019) yang menyatakan bahwa bahan ajar perlu dipilah agar mempermudah proses belajar dalam hal ini untuk jenjang SMK.

Hasil observasi menunjukkan bahwa di SMKN 10 Surabaya telah menerapkan kurikulum 2013 terbaru. Dalam pelaksanaan pembelajaran, pendidik untuk mengajar menggunakan Lembar Kerja Siswa yang ditunjang dengan buku paket yang masih memakai kurikulum KTSP. Lembar Kerja Siswa berisi materi yang terlalu ringkas, bersifat tekstual, dan lebih banyak berupa contoh-contoh soal. Sedangkan untuk referensi buku Akuntansi Perbankan secara umum di pasaran, telah banyak buku yang tersedia. Namun, isinya masih belum mencakup keseluruhan dari kompetensi dasar yang ada di silabus SMK. Fenomena terkait minimnya ketersediaan referensi buku yang sesuai dengan kompetensi dasar di SMK tersebut didukung dengan hasil wawancara peneliti dengan salah satu pendidik di SMKN 10 Surabaya yang menyatakan bahwa pilihan bahan ajar kompetensi keahlian akuntansi perbankan yang sejalan dengan kurikulum dan kompetensi dasar untuk peserta didik SMK saat ini memang masih minim dan perlu adanya pengembangan bahan ajar.

Dari fenonema diatas untuk menunjang kegiatan pembelajaran yang sesuai dengan kurikulum dan dapat memudahkan peserta didik, serta dapat menambah referensi buku yang sesuai dengan kompetensi dasar di SMK, peneliti terdorong untuk mengembangkan produk bahan ajar akuntansi perbankan kelas XI Perbankan berbasis Contextual Teaching and Learning (CTL). Kelebihan produk ini adalah menggunakan uraian materi dan contoh-contoh soal yang lebih kontekstual. Sehingga, dapat memudahkan pemahaman materi dan merangsang peserta didik untuk berfikir kritis. Selanjutnya memiliki fitur $Q R$ Code sebagai penunjang bahan ajar dalam proses pembelajaran khususnya ketika peserta didik di tahap mengumpulkan informasi, agar informasi yang didapat lebih relevan. bahan ajar ini juga 
memiliki fitur "Jendela Perbankan" yang diakses dengan menggunakan $Q R$ Code dan fitur Bank Ilmu. $Q R$ Code digunakan karena dapat menunjang kegiatan pembelajaran dan membantu peserta didik (Rikala \& Kankaaranta, 2012). Dalam hal ini, $Q R$ Code dapat membantu guru untuk memberikan dan mengarahkan peserta untuk memilih sumber informasi belajar yang relevan dan mudah diakses. Hal tersebut sesuai dengan penelitian Durak, Ozkeskin, dan Ataizi (2016) yang menyatakan bahwa dengan memanfaatkan Handphone, $Q R$ Code dapat diakses untuk menghubungkan pengguna pada informasi yang dituju dengan mudah dan cepat.

Penelitian ini memiliki relevansi dengan beberapa penelitian terdahulu yaitu, penelitian dari Alawiyah \& Susanti (2019) dengan judul "Pengembangan Bahan Ajar Berbasis Kontekstual Pada Mata Pelajaran Akuntansi Perbankan Dan Keuangan Mikro Untuk Peserta Didik Kelas XI SMK Kompetensi Keahlian Perbankan Dan Keuangan Mikro". Hasil penelitiannya menunjukkan bahan ajarnya sangat layak diaplikasikan dalam Pembalajaran. Penelitian dari Palupi \& Susanti (2019) dengan judul "The Development of Tax Administration Module Contextual Based on the Fiscal Reconciliation Material for Vocational School" dengan hasil presentase kelayakan rata-rata dari bahan ajar memperoleh kriteria "sangat layak". Dan penelitian dari Zulyadaini (2017) berjudul "A Development of Students Worksheet Based on Contextual Teaching and Learning", hasilnya produk berbasis CTL yang dikembangkan dinyatakan "layak"untuk digunakan.

Dari pemaparan diatas, peneliti akan melakukan penelitian berjudul "Pengembangan Bahan Ajar Mata Pelajaran Akuntansi Perbankan dan Keuangan Mikro Kelas XI Perbankan Berbasis Contextual Teaching and Learning (CTL)". Berdasarkan paparan diatas, maka timbul rumusan masalah: 1) Bagaimana proses "pengembangan Bahan Ajar Mata Pelajaran Akuntansi Perbankan dan Keuangan Mikro Berbasis Contextual Teaching and Learning (CTL)"; 2) Bagaimana kelayakan "Bahan Ajar Mata Pelajaran Akuntansi Perbankan dan Keuangan Mikro Berbasis Contextual Teaching and Learning (CTL)". Berdasarkan rumusan masalah, maka tujuan penelitiannya: 1) Menghasilkan produk berupa "Bahan Ajar Mata Pelajaran Akuntansi Perbankan dan Keuangan Mikro Berbasis Contextual Teaching and Learning (CTL)"; 2) Menganalisis kelayakan "Bahan Ajar Mata Pelajaran Akuntansi Perbankan dan Keuangan Mikro Berbasis Contextual Teaching and Learning (CTL)”.

\title{
Metode Penelitian
}

Model pengembangan dipilih adalah 4-D dari Thiagarajan, Semmel, dan Semmel, yaitu define, design, development, dan disseminate (Trianto, 2015) yang terbatas pada tahap ketiga (development) karena terbatasnya waktu dan biaya.

Subjek dalam penelitian ini ialah peserta didik kelas XI SMK Kompetensi Keahlian Perbankan. Jenis data yang dipilih ialah kuantitatif dan kualitatif. Data kuantitatifnya berupa skor olah data validasi dari validator yang berbentuk angka yang analisisnya menghasilkan bentuk presentase, dan data kualitatifnya berupa catatan-catatan dari penelaah setelah produk ditelaah dan kemudian hasilnya akan di deskripsikan sebagai acuan untuk melakukan perbaikan.

Instrumen penelitian yang dipilih ialah angket terbuka dan angket tertutup. Angket terbuka terdiri dari lembar untuk penelaah materi, kebahasaan, dan kegrafikan. Sedangkan angket tertutup terdiri dari lembar untuk validator materi, kebahasaan, dan kegrafikan. Kisikisi instrumen didasarkan pada kriteria kelayakan bahan ajar dari BSNP 2014.

Teknik analisis data yang dipilih ialah analisis kualitatif, dan analisis kuantitatif. Lembar untuk penelaah analisisnya dengan teknik deskriptif kualitatif. Lembar telaah ini

\author{
p-ISSN 2337-571X | e-ISSN $\underline{2541-562 X}$ \\ (C) 2020 Edunomic: Jurnal Ilmiah Pendidikan Ekonomi \\ Fakultas Keguruan dan Ilmu Pendidikan
}


berisi masukan dan kritikan dari guru pengampu mata pelajaran dan para dosen ahli untuk memperbaiki dan menyempurnakan bahan ajar yang dikembangkan. Sedangkan analisis lembar validasi para ahli analisisnya menggunakan teknik deskripsi kuantitatif yang menghasilkan persentase yang diperoleh dari kriteria penilaian "skala likert".

Tabel 2.1

Kriteria Skor Skala Likert

\begin{tabular}{ll}
\hline Kriteria & Skor \\
\hline Sangat baik & 5 \\
Baik & 4 \\
Sedang & 3 \\
Buruk & 2 \\
Buruk sekali & 1 \\
\hline
\end{tabular}

\section{Sumber: Riduwan (2016)}

Cara analisisnya adalah:

Nilai kelayakan $=\frac{\text { Jumlah nilai }}{\text { Jumlah nilai maksimal }} \times 100 \%$

Setelah memperoleh hasil prosentase, maka akan dapat di interpretasikan kelayakan hasil bahan ajar dengan kategori:

Tabel 2.2

Kriteria Interpretasi Kelayakan

\begin{tabular}{ll}
\hline Penilaian & Kriteria Interpretasi \\
\hline $0 \%-20 \%$ & Sangat tidak layak \\
$21 \%-40 \%$ & Tidak layak \\
$41 \%-60 \%$ & Cukup layak \\
$61 \%-80 \%$ & Layak \\
$81 \%-100 \%$ & Sangat layak \\
\hline
\end{tabular}

Sumber: Riduwan (2016)

Dari penyajian kedua tabel diatas, menunjukkan bahwa "Bahan ajar mata pelajaran akuntansi perbankan berbasis Contextual Teaching and Learning (CTL)" dinyatakan "layak" apabila didapatkan skor rerata sebesar $\geq 61 \%$.

\section{Hasil dan Pembahasan}

\section{Proses Pengembangan Bahan Ajar.}

Pengembangan bahan ajar akuntansi perbankan berbasis Contextual Teaching and Learning (CTL) dilakukan dengan model pengembangan 4-D dari Thiagarajan, Semmel, dan Semmel, yaitu pendefinisian (define), perancangan (design), Pengembangan (develop), dan penyebaran (disseminate) namun, tahap penyebaran (disseminate) tidak dilakukan karena terbatasnya biaya dan waktu.

Tahap pendefinisian (define). Terdapat 5 tahap pokok didalamnya, yaitu analisis ujung depan, peserta didik, tugas, konsep, dan perumusan tujuan pembelajaran. Analisis ujung depan, pada tahap ini diketahui bahwa SMKN 10 Surabaya saat ini menggunakan kurikulum terbaru. Dalam pelaksanaan pembelajaran akuntansi perbankan dikelas, pendidik 
menggunakan Lembar Kerja Siswa dan di tunjang dengan buku paket berbasis KTSP. Untuk uraian isi materinya masih terlalu ringkas, bersifat tekstual, dan lebih banyak berisi soal-soal latihan. Sedangkan buku paket penunjangnya masih memakai kurikulum KTSP. Sehingga, isi materinya belum menunjang pembelajaran berdasarkan kurikulum 2013. Hal tersebut cukup menyulitkan peserta didik.

Analisis peserta didik. Peserta didik kelas XI Perbankan SMKN 10 Surabaya secara usia sudah dapat beradaptasi dengan penerapan kurikulum 2013 di sekolah, sehingga sudah mampu belajar secara mandiri dan dapat memahami konsep uraian materi pada bahan ajar serta mampu mengerjakan soal-soal latihan yang bersifat kontekstual. Peserta didik juga merasa membutuhkan ilustrasi-ilustrasi yang sesuai dengan materi yang dibahas untuk memperjelas dan memudahkan mereka dalam memahami materi. Hal tersebut disebabkan karena peserta didik merasakan kesulitan dalam memahami materi akuntansi perbankan dengan buku ajar yang digunakan sehari-hari.

Analisis tugas. Merupakan penentuan pembuatan tugas kemudian diselesaikan peserta didik. Dalam bahan ajar ini berisikan tujuh kompetensi dasar yaitu KD 3.1 - KD 3.7 atau untuk semester gasal. Bahan ajar ini digunakan dalam pembelajaran dengan alokasi waktu $3 \mathrm{x}$ 45 menit ( $4 \mathrm{x}$ pertemuan) pada tiap kompetensi dasarnya. Tugas-tugas yang perlu dilakukan oleh peserta didik adalah memahami kompetensi dasar, tujuan pembelajaran, dan konsep dasar dari setiap bab, lalu peserta didik harus memahami uraian materi yang disajikan dalam buku beserta memanfaatkan fitur-fitur yang telah disediakan. Selain itu, dalam bahan ajar juga terdapat tugas-tugas pada setiap kompetensi dasar (KD) yang terdiri dari tugas mengamati pada tahap pengamatan, terdapat soal-soal studi kasus yang harus dikerjakan ketika kegiatan berkelompok pada tahap mengasosiasi di setiap bab. Sedangkan untuk soal evaluasi berbentuk pilihan ganda dan uraian dengan masing-masing sejumlah 10 dan 5 nomor. Didalam bahan ajar juga telah dilengkapi dengan tahapan kegiatan $5 \mathrm{M}$.

Analisis konsep. Merupakan penentuan rancangan materi. Rancangan ini akan dibuat secara ringkas dalam peta konsep pada awal tiap bab sehingga peserta didik akan mengerti isi materi yang akan dipelajari selama pembelaajaran. Perumusan tujuan pembelajaran untuk menentukan tujuan pembelajaran yang diturunkan dari $\mathrm{KD}$ dan indikator pembelajaran. Dalam hal ini kompetensi yang dibahas adalah: KD 3.1 Perbedaan akuntansi perbankan dan keuangan, KD 3.2 Persamaan dasar akuntansi perbankan, KD 3.3 Mekanisme debet dan kredit akuntansi perbankan, KD 3.4 Akuntansi tabungan, KD 3.5 Akuntansi giro, KD 3.6 Akuntansi deposito, dan KD 3.7 Akuntansi kredit.

Tahap perancangan (design). Tahap ini sebagai penentuan struktur dan susunan bahan ajar. Hasil dari penentuan tersebut akan menghasilkan prototype 1. Pemilihan format untuk bahan ajar yang dikembangkan adalah menggunakan BSNP (2014) dengan dimodifikasi oleh peneliti dan penyusunan bahan ajar akan dikembangkan dan di susun sesuai dengan format serta dicetak. Didalam bahan ajar uraian isinya terdapat kegiatan $5 \mathrm{M}$, yaitu kegiatan "ayo mengamati", "ayo menanya", "ayo mencari informasi", "ayo mengasosiasi", dan "ayo mengkomunikasikan". Bahan ajar juga memiliki kelebihan diantaranya berbasis CTL pada contoh-contoh soalnya dan memiliki beberapa fitur yang tersedia, diantaranya terdapat Jendela Perbankan,dengan berbantu $Q R$ Code untuk pengaksesan dan Bank Ilmu. Fitur Jendela perbankan terdapat pada sesudah tahap ayo mencari informasi, oleh karena itu didalamnya memuat alamat website yang berisikan informasi-informasi tambahan yang dapat menambah wawasan ilmu pengetahun peserta didik berkaitan dengan materi yang sedang dibahas. Cara kerjanya adalah peserta didik dapat melakukan scanning terhadap $Q R$ Code yang telah tersedia dalam buku tersebut yang kemudian secara otomatis akan mengarahkan

$p-I S S N \underline{2337-571 X} \mid$ e-ISSN 2541-562X

(C) 2020 Edunomic: Jurnal Ilmiah Pendidikan Ekonomi Fakultas Keguruan dan Ilmu Pendidikan 
peserta didik menuju alamat website yang dituju. Fitur Jendela Perbankan tersebut berfungsi agar sumber-sumber informasi yang diperoleh oleh peserta didik menjadi relevan dan sesuai dengan materi yang sedang dibahas. Selain itu, $Q R$ Code juga membantu peserta didik ketika memasuki tahap mengasosiasi yaitu ketika kegiatan berkelompok untuk mengerjakan soal studi kasus. Soal studi kasus yang basisnya online, maka peserta didik dapat mengaksesnya melalui scanning dengan $Q R$ Code yang telah disediakan tersebut. Kemudian terdapat fitur bernama Bank Ilmu. Fitur ini berfungsi untuk menjelaskan makna dari kata, istilah, atau pernyataan yang dianggap asing oleh peserta didik, sehingga akan membantu peserta didik untuk memahami makna yang dimaksud. Fitur Bank Ilmu ini terdapat pada tahap ayo mencari informasi maupun pada tahap ayo mengkomunikasikan disesuikan dengan materi dalam buku.

Tahap Pengembangan (develop). Tahap ini akan dilakukan telaah pada prototype 1 dengan pemberian saran perbaikan oleh penelaah. Hasilnya akan diperoleh produk prototype 2 yang kemudian akan divalidasi oleh para validator.

Berikut adalah hasil telaah dari segi materi:

Tabel 3.1

Hasil Telaah Materi

\begin{tabular}{cll}
\hline No & Aspek & \multicolumn{1}{c}{ Hasil dan Perbaikan } \\
\hline 1. & Isi dan penyajian & Hasil telaah untuk uraian isi produk \\
& & telah sesuai dengan komponen yang \\
& ditetapkan yaitu kesesuaian dengan \\
& pengetahuan dan keterampilan \\
& untuk siswa, sehingga tidak perlu \\
& adanya perbaikan. Untuk penyajian \\
& buku, oleh penelaah juga telah \\
& dinyatakan sesuai dan lengkap \\
& dengan kriteria-kriteria yang telah \\
& ditetapkan oleh penelaah, sehingga \\
& tidak perlu adanya perbaikan \\
\hline & Hasil telaah menunjukkan bahwa \\
& untuk soal evaluasi masih perlu \\
& adanya penyesuaian yaitu pada \\
& tingkatan soal yaitu minimal harus \\
& pada tingkatan C3, dan perlu \\
& adanya penambahan soal studi \\
& kasus pada produk bahan ajar yang \\
& dikembangkan. \\
\hline
\end{tabular}

Sumber: Hasil Olah Data Peneliti (2020)

Selanjutnya, Hasil telaah dari segi kebahasaan, hasilnya adalah sebagai berikut:

p-ISSN 2337-571X | e-ISSN 2541-562X 
Tabel 3.2

Hasil Telaah Kebahasaan

\begin{tabular}{cll}
\hline No & Aspek & \multicolumn{1}{c}{ Hasil dan Perbaikan } \\
\hline 1. & Kebahasaan & Hasil telaah dari segi kebahasaan \\
& menunjukkan hasil bahwa \\
& penulisan isi produk sudah cukup \\
& baik, hanya memerlukan sedikit \\
& perbaikan seperti pada penggunaan \\
& kata baku, huruf miring, tanda baca, \\
& dan konjungsi. Sedangkan dari \\
& aspek lainnya,sudah dinyatakan \\
& sesuai oleh penelaah \\
\hline
\end{tabular}

Sumber: Hasil Olah Data Peneliti (2020

Hasil telaah dari segi kegrafikan, hasilnya adalah sebagai berikut:

Tabel 3.3

Hasil Telaah Kegrafikan

\begin{tabular}{cll}
\hline No & Aspek & \multicolumn{1}{c}{ Hasil dan Perbaikan } \\
\hline 1. & Kegrafikan & Hasil telaah dari segi kegrafikan \\
& menunjukkan hasil bahwa perlu \\
& adanya beberapa perbaikan \\
& diantaranya, perbaikan kombinasi \\
& warna yang dipilih untuk sampul \\
& depan, pemilihan jenis dan ukuran \\
& huruf untuk halaman setelah \\
& sampul, dan tidak terlalu \\
& menggunakan warna merah yang \\
& terlalu dominan. Setelah dilakukan \\
& satu kali perbaikan tersebut, \\
& penelaah menyatakan bahwa \\
& kualitas produk sudah baik sekali, \\
& pengerjaan tata letak isi pada layout \\
& amat teliti dan telah memenuhi \\
& seluruh prinsip desain dan layak \\
& digunakan.
\end{tabular}

Sumber: Hasil Olah data Peneliti (2020)

\section{Kelayakan Bahan Ajar}

Kelayakan bahan ajar diperoleh setelah dilakukan hasil olah data dari para validator. Berikut adalah hasil validasinya:

Hasil telaah dan validasi diperoleh dari salah satu satu dosen Prodi Pendidikan Akuntansi UNESA yaitu Rochmawati, S.Pd., M.Ak dan salah satu guru pengampu perbankan dari SMKN 10 Surabaya yaitu Dra. Kusriatin, M.M dengan rekapitulasi sebagai berikut: 
Tabel 3.4

Hasil Validasi Ahli Materi

\begin{tabular}{clcc}
\hline No & \multicolumn{1}{c}{ Aspek } & Persentase & Kriteria \\
\hline 1. & Kelayakan Isi & $84 \%$ & Sangat layak \\
2. & Kelayakan & $88 \%$ & Sangat layak \\
& $\begin{array}{l}\text { Penyajian } \\
\text { Rata-rata }\end{array}$ & $86 \%$ & Sangat layak \\
& $\begin{array}{l}\text { kelayakan } \\
\text { materi }\end{array}$ & & \\
\hline
\end{tabular}

\section{Sumber: Hasil olah data peneliti (2020)}

Penjelasan dari tabel 3 yaitu, hasil validasi menghasilkan kelayakan dari bahan ajar yang dikembangkan diperoleh masing-masing presentase $84 \%$ dan $88 \%$ untuk kelayakan isi dan penyajian. Kemudian diperoleh rerata kelayakan materi $86 \%$ dengan kategori "sangat layak". Menurut Riduwan (2016), apabila diperoleh peresentase 81\%-100\% maka termasuk kategori "sangat layak", sehingga isi dan penyajian bahan ajar "sangat layak" digunakan di pembelajaran. Menurut ahli materi, uraian isi materi telah tersusun dengan baik sesuai dengan konsep. Materi yang disajikan juga telah dilengkapi dengan ilustrasi-ilustrasi yang sesuai, serta contoh-contoh soal yang telah bersifat kontekstual. Hal tersebut telah sesuai karena yang bersifat kontekstual dari dalam sebuah bahan ajar adalah terletak pada contoh-contoh soalnya.

Untuk ahli kebahasaan, hasil telaah dan validasi diperoleh dari dosen Fakultas Bahasa dan Seni UNESA yaitu, Arie Yuanita, S.S., M.Si dengan rekapitulasi sebagai berikut:

\section{Tabel 3.5}

Hasil Validasi Ahli Kebahasaan

\begin{tabular}{clcc}
\hline No & \multicolumn{1}{c}{ Aspek } & Persentase & Kriteria \\
\hline 1. & Tingkat kesesuaian & $80 \%$ & Layak \\
perkembangan siswa. & & \\
2. & Keterbacaan & $80 \%$ & Layak \\
3. & Memotivasi. & $80 \%$ & Layak \\
4. & Kelugasan. & $80 \%$ & Layak \\
5. & $\begin{array}{l}\text { Alur pikir yang } \\
\text { koheren dan runtut. }\end{array}$ & $80 \%$ & Layak \\
6. Sesuai kaidah & $80 \%$ & Layak \\
& $\begin{array}{l}\text { bahasa Indonesia. } \\
\text { 7. Istilah, Simbol, dan }\end{array}$ & $80 \%$ & Layak \\
& $\begin{array}{l}\text { Lambang. kelayakan } \\
\text { Rerata } \\
\text { kebahasaan }\end{array}$ & $80 \%$ & Layak \\
\hline
\end{tabular}

Sumber: Hasil olah data peneliti (2020)

Penjelasan dari tabel 4 yaitu, berdasarkan ahli kebahasaan persentase yang diperoleh dari beberapa aspek bahasa menghasilkan rata-rata kelayakan kebahasaan sebesar $80 \%$ dan memperoleh kriteria "layak". Menurut ahli kebahasaan, ejaan dari isi buku memenuhi PUEBI. Hasil tersebut sesuai dengan pernyataan Riduwan (2016), bahwa apabila memperoleh persentase $61 \%-80 \%$ kategori yang didapat adalah "layak". 
Untuk ahli kegrafikan, hasil telaah dan validasi diperoleh dari dosen jurusan Kurikulum dan Teknologi Pendidikan Fakultas Ilmu Pendidikan UNESA yaitu Irena Yolanita Maureen, S.Pd., M.Sc dengan hasil validasi:

Tabel 3.6

Hasil Validasi Ahli Kegrafikan

\begin{tabular}{clcl}
\hline No & \multicolumn{1}{c}{ Aspek } & Persentase & Kriteria \\
\hline 1. & Ukuran & $100 \%$ & Sangat layak \\
2. & Desain Sampul & $96,7 \%$ & Sangat layak \\
3. & Desain Isi & $100 \%$ & Sangat layak \\
& Rerata & $98,9 \%$ & Sangat layak \\
& kelayakan & & \\
& kegrafikan & & \\
\hline
\end{tabular}

Sumber: Hasil olah data peneliti (2020)

Penjelasan dari tabel 5, berdasarkan ahli kegrafikan dari bahan ajar yang dikembangkan menghasilkan persentase dari beberapa aspek yang kemudian menghasilkan rerata kelayakan kegrafikan 98,9\% dengan kriteria "sangat layak". Menurut Riduwan (2016), apabila diperoleh peresentase 81\%-100\% maka diperoleh kategori "sangat layak", sehingga secara kegrafikan, bahan ajar telah "sangat layak" digunakan. Sedangkan menurut ahli grafis, ukuran, desain sampul, dan isi bahan ajar telah sesuai.

Tabel 3.7

Rata-Rata Hasil Validasi Ahli

\begin{tabular}{clcc}
\hline No & Aspek & Persentase & Kriteria \\
\hline 1. & Materi & $86 \%$ & Sangat Layak \\
2. & Kebahasaan & $80 \%$ & Layak \\
3. & Kegrafikan & $98,9 \%$ & Sangat layak \\
& Rerata & $88,3 \%$ & Sangat layak \\
& Persentase & & \\
\hline
\end{tabular}

Sumber: Hasil Olah data Peneliti (2020)

Tabel 6 menunjukkan, rerata hasil validasi menunjukkan presentase $88,3 \%$, hal tersebut sejalan dengan pernyataan Ridwan (2016) bahwa dengan presentase $\geq 61 \%$ maka memperoleh kategori "sangat layak". Hasil tersebut didukung penelitian sejenis oleh Sumaeny dan Susanti (2018) yang mengembangkan bahan ajar akuntansi perbankan berbasis CTL dengan persentase rerata dari para ahli $86,51 \%$ sehingga "sangat layak" digunakan. Selanjutnya dari Rahmawati dan Susilowibowo (2019) yang mengembangkan bahan ajar akuntansi keuangan berbasis CTL memperoleh rerata dari para ahli sebesar 80,85\% dengan kategori "layak".

\section{Simpulan}

Simpulan dari penelitian ini, proses "pengembangan bahan ajar akuntansi perbankan berbasis Contextual Teaching and Learning (CTL)" melalui tahapan telaah dan validasi oleh para penelaah dan validator. Model pengembangan yang digunakan 4-D dari Thiagarajan, Semmel, dan Semmel terbatas pada tahap (develop). Kelayakan bahan ajar didapatkan setelah melalui hasil olah data. Kelayakan bahan ajar mendapatkan kriteria "sangat layak", dinilai dari segi isi dan penyajian materi, serta kegrafikan. Sedangkan dari segi kebahasaan mendapatkan kriteria "layak". Bahan ajar yang dikembangkan berbasis kontekstual dan berisikan Kompetensi Dasar 3.1 - 3.7 untuk kelas XI SMK Kompetensi Keahlian Perbankan. 
Didalam bahan ajar terdapat beberapa fitur pendukung seperti fitur "Jendela Perbankan", "Bank Ilmu" yang ditunjang dengan QR Code. Selain itu, bahan ajar telah memuat tahapan pembelajaran saintifik 5M.

\section{Referensi}

Alawiyah, M., \& Susanti (2019). Pengembangan Bahan Ajar Berbasis Kontekstual Pada Mata Pelajaran Akuntansi Perbankan Dan Keuangan Mikro Untuk Peserta Didik Kelas Xi Smk Kompetensi Keahlian Perbankan Dan Keuangan Mikro. Jurnal Pendidikan Akuntansi (JPAK), 7(3), 422-427.

Durak, G., Ozkeskin, E., \& Ataizi, M. (2016). QR Codes In Education and Communication. Turkish Online Jurnal of Distance Education, 17(2), 42-58.

Hamalik, O. (2015). Kurikulum dan Pembelajaran. Jakarta: PT. Bumi Aksara.

Johnson, Elaine. B. (2007). Contextual Teaching and Learning: Menjadikan Kegiatan Belajar-Mengajar Mengasyikkan dan Bermakna. Bandung: Mizan Learning Center (MLC).

Komalasari, K. (2017). Pembelajaran Kontekstual: Konsep dan Aplikasi. Bandung: PT Refika Aditama.

Ma'sum, A \& Rochmawati (2019). Pengembangan Bahan Ajar Berbasis Saintifik Sebagai Suplemen Mata Pelajaran Praktikum Akuntansi Lembaga/Instansi Pemerintah Kelas XI Materi Akuntansi Desa. Jurnal Pendidikan Akuntansi (JPAK), 7 (3), 434-441.

Nasution. (2013). Berbagai Pendektan Dalam Proses Belajar Mengajar. Jakarta: PT.Bumi Aksara.

Palupi, R.A \& Susanti (2019). The Development of Tax Administration Module Contextual Based on the Fiscal Reconciliation Material for Vocational School. International Conference on Economics, Education, Business, and Accounting, 3(11), 329-347. Knepublishing.com.

Pertiwi, D.R., \& Rochmawati (2019). Pengembangan Bahan Ajar Akuntansi Perbankan dan Keuangan Mikro Berbasis Pendekatan Saintifik Kelas XI Perbankan dan Keuangan Mikro SMK Negeri 1 Jombang. Jurnal Pendidikan Akuntansi (JPAK), 7(2), 182-188.

Prastowo, A. (2015). Panduan Kreatif Membuat Bahan Ajar Inovatif. Jogjakarta: DIVA Press.

Rahmawati, N.D., \& Susilowibowo, J. (2019). Pengembangan Bahan Ajar Berbasis Kontekstual Mata Pelajaran Akuntansi Dasar Untuk Kelas X Kompetensi Keahlian Akuntansi Dan Keuangan Lembaga Semester 2 Smk Negeri 10 Surabaya. Jurnal Pendidikan Akuntansi (JPAK), 7(3), 360-365.

Rahmawati, S., \& Susanti (2019). Pengembangan Bahan Ajar E-Book Pada Mata Pelajaran Praktikum Akuntansi Lembaga Berbasis Kontekstual untuk SMK. Jurnal Pendidikan Akuntansi (JPAK), 7(3), 383-391.

Rikala, J., \& Kankaaranta, M (2012). The Use of Quick Response Codes in the Classroom. Conference: 11th World Conference on Mobile and Contextual Learning. University of Jyvaskyla

Riduwan. (2016). Skala Pengukuran Variabel-Variabel Penelitian. Bandung: CV.Alfabeta Sagala, S. (2012). Konsep dan Makna Pembelajaran. Bandung: Alfabeta.

Sumaeny, R.N., \& Susanti. (2018). Pengembangan Bahan Ajar Akuntansi Perbankan Berbasis Kontekstual Sebagai Pendukung Implementasi Kurikulum 2013 Pada Materi Komitmen Dan Kontijensi Kelas XI Perbankan Di SMK Negeri 10 Surabaya. Jurnal Pendidikan Akuntansi (JPAK), 6(3), 195-200. 
Susanti, \& Rochmawati (2017). Akuntansi Perbankan. Surabaya: UNESA UNIVERSITY PRESS.

Toyib, M., Martono, T., \& Sawiji, H. (2015). Pengembangan Bahan Ajar Kewirausahaan dengan Pendekatan Contextual Teaching and Learning di Program Studi Pendidikan Akuntansi FKIP Universitas Negeri Palembang Tahun 2014. Jurnal FKIP UNS, 1(2).

Trianto. (2015). Mendesain Model Pembelajaran Inovatif, Progresif dan Kontekstual. Jakarta: Prenadamedia Group.

Uno, Hamzah B. (2016). Model Pembelajaran: Menciptakan Proses Belajar Mengajar yang Kreatif dan Efektif. Jakarta: PT. Bumi Aksara.

Widiyawati, L., \& Susanti (2017). Pengembangan Modul Administrasi Pajak Berbasis Kontekstual pada Materi Pajak Penghasilan (PPh) Pasal 21 untuk Siswa Kelas XII Akuntansi SMK Negeri di Surabaya. Jurnal Pendidikan Akuntansi (JPAK), 5(1), 1-7.

Zulyadaini. (2017). A Development of Students' Worksheet Based on Contextual Teaching and Learning, Batanghari University. Batanghari University, 13(1), 30-38. 